\title{
Comparative Genomics Identifies Candidate Genes for Infectious Salmon Anemia (ISA) Resistance in Atlantic Salmon (Salmo salar)
}

\author{
Jieying Li • Keith A. Boroevich • Ben F. Koop • \\ William S. Davidson
}

Received: 19 December 2009 / Accepted: 4 March 2010/Published online: 16 April 2010

(C) The Author(s) 2010. This article is published with open access at Springerlink.com

\begin{abstract}
Infectious salmon anemia (ISA) has been described as the hoof and mouth disease of salmon farming. ISA is caused by a lethal and highly communicable virus, which can have a major impact on salmon aquaculture, as demonstrated by an outbreak in Chile in 2007. A quantitative trait locus (QTL) for ISA resistance has been mapped to three microsatellite markers on linkage group (LG) 8 (Chr 15) on the Atlantic salmon genetic map. We identified bacterial artificial chromosome (BAC) clones and three fingerprint contigs from the Atlantic salmon physical map that contains these markers. We made use of the extensive BAC end sequence database to extend these contigs by chromosome walking and identified additional two markers in this region. The BAC end sequences were used to search for conserved synteny between this segment of LG8 and the fish genomes that have been sequenced. An examination of the genes in the syntenic segments of the tetraodon and medaka genomes identified candidates for association with ISA resistance in Atlantic salmon based on differential expression profiles from ISA challenges or on the putative biological functions of the proteins they encode. One gene in particular, HIV-EP2/MBP-2, caught our attention as it may influence the expression of
\end{abstract}

Electronic supplementary material The online version of this article (doi:10.1007/s10126-010-9284-0) contains supplementary material, which is available to authorized users.

J. Li · K. A. Boroevich • W. S. Davidson $(\bowtie)$

Department of Molecular Biology and Biochemistry,

Simon Fraser University,

8888 University Drive,

Burnaby, BC, Canada V5A 1S6

e-mail: wdavidso@sfu.ca

B. F. Koop

Department of Biology, University of Victoria,

Victoria, BC, Canada V8W 3N5 several genes that have been implicated in the response to infection by infectious salmon anemia virus (ISAV). Therefore, we suggest that HIV-EP2/MBP-2 is a very strong candidate for the gene associated with the ISAV resistance QTL in Atlantic salmon and is worthy of further study.

Keywords Infectious salmon anemia Atlantic salmon . Disease resistance $\cdot$ Comparative genomics

\section{Introduction}

Infectious salmon anemia (ISA) is a highly communicable viral disease that affects salmonids. ISA can be particularly devastating to marine-farmed Atlantic salmon with cumulative mortalities ranging up to $100 \%$ in some instances. ISA was first recognized as a new disease entity in Atlantic salmon in 1984 in Norway (Thorud and Djupvik 1988), and since then, outbreaks have occurred in Scotland, the Faroe Islands, Denmark, Maine, and eastern Canada (see Kibenge et al. 2004 for details). ISA has also recently had a major negative impact on salmon production in Chile (Godoy et al. 2008). Such is the threat to salmon aquaculture that ISA is on the European Union list of the most dangerous fish diseases.

The causative agent of ISA is infectious salmon anemia virus (ISAV), which is classified as a member of the Orthomyxoviridae and the only species in the genus Isavirus (Falk et al. 1997; Rimstad and Mjaaland 2002). The biochemical events involved in the infection and replication of ISAV are similar (Eliassen et al. 2000; Rimstad and Mjaaland 2002; Hellebo et al. 2004) but not identical (Falk et al. 1997; Krossoy et al. 2001) to what has been observed in their relatives, the influenza viruses. The genome of ISAV resembles that of influenza virus A as it is composed of eight linear single-stranded, negative-sense 
RNA segments with a total size of $14.3 \mathrm{~kb}$, which encode at least ten proteins, nine of which are structural (Falk et al. 2004; Kibenge et al. 2004).

Although vaccination is used successfully in Atlantic salmon farming to control many bacterial diseases, effective vaccines against viral diseases have proved more difficult to produce. An alternative strategy is to identify quantitative trait loci (QTL) affecting resistance to the viruses and to make use of this information in a marker assisted selection breeding program. Gjoen et al. (1997) showed that there is a genetic component to ISA resistance in Atlantic salmon and estimated the narrow-sense heritability to be 0.19 . A preliminary study using amplified fragment length polymorphisms and a multistage testing strategy identified several putative QTL (Moen et al. 2004a), and it was subsequently shown by the addition of microsatellite markers that a major QTL is located on linkage group (LG) 8 in the Atlantic salmon genetic map (Moen et al. 2004b). The recent integration of the linkage map and karyotype (Phillips et al. 2009) showed that LG8 corresponds to chromosome (Chr) 15, and this nomenclature will be used hereafter. Further investigation confirmed the presence of the QTL for ISA resistance on Chr15 in Atlantic salmon and showed that this QTL explains a significant fraction (32-47\%) of the additive genetic variation of the trait (Moen et al. 2007). However, a transmission disequilibrium test and combined linkage disequilibrium/linkage analysis revealed that the QTL markers were not in a population-wide association with ISA resistance, highlighting the need for finer mapping and/ or the use of salmon genomic resources to identify the gene and the functional polymorphism itself.

Over the past decade, many genomic resources have been developed for Atlantic salmon, much of them through the Norwegian Salmon Genome Project, the Genomic Research on Atlantic Salmon Project (GRASP), and their successor, Consortium for Genomic Research on All Salmonids Project (cGRASP). These include the construction of a bacterial artificial chromosome (BAC) library (CHORI-214; Thorsen et al. 2005), a physical map comprising 4,300 contigs based on Hind III fingerprinting of 223,781 BACs in $\mathrm{Ng}$ et al. (2005), 207,869 BAC end sequences that cover $\sim 3.5 \%$ of the genome sequence and linkage maps with 1,600 markers (Danzmann et al. 2008; Moen et al. 2008; Lorenz et al. 2009). More than half of the genetic markers are microsatellites or SNPs derived from $\mathrm{BAC}$ end sequences, and these have recently been used to integrate the linkage map, the physical map, and the Atlantic salmon karyotype (Phillips et al. 2009). In addition, 495,000 ESTs have been generated (Rise et al. 2004; Adzhubei et al. 2007; Koop et al. 2008) and used to construct microarrays for expression studies (Rise et al. 2004; von Schalburg et al. 2008; Koop et al. 2008). These genomic resources have been amalgamated and are publicly accessible at www.asalbase.org.

In the absence of a sequence for the genome of the Atlantic salmon, we wondered if it would be feasible to link these salmon genomic resources associated with ISA to the sequenced genomes of other teleosts, in particular those of the pufferfish (Tetraodon nigroviridis), medaka (Oryzias latipes), zebrafish (Danio rerio), and three-spined stickleback (Gasterosteus aculateus), in the manner illustrated by Sarropoulou et al. (2008) for the commercially important fish species: Sparus aurata, Dicentrarchus labrax, and Oreochromis spp. This approach has been used successfully to identify candidate genes for QTL in the blind Mexican cavefish, Astyanax mexicanus, based on conservation of synteny with zebrafish (Gross et al. 2008). Here, we report the results of a search for candidate genes associated with the ISA resistance QTL in Atlantic salmon using comparative genomics.

\section{Materials and Methods}

Design of Oligonucleotide Hybridization Probes and Polymerase Chain Reaction Primers

Prior to probe and primer design, the sequences of the microsatellite markers and their flanking regions were first masked for repetitive DNA using the Repeat Masker program on the University of Victoria cGRASP website (http://lucy.ceh.uvic.ca/repeatmasker/cbr_repeatmasker.py). Then, the masked sequences were used as the input to design oligonucleotide probes (40 mers) and corresponding complementary primers (20 mers) using OLIGO 4.0 software (Rychlik and Rhoads 1989). The oligonucleotides were designed such that they had a GC content of $50 \%$ or higher, with a $\mathrm{Tm}$ of the probe at least $55^{\circ} \mathrm{C}$. The probes and primers used in this study are listed in Table 1.

Identification of BACs Containing Specific Microsatellites and their Assignment to Fingerprint Contigs

We screened the CHORI-214 Atlantic salmon BAC library (Thorsen et al. 2005) with the 40-mer probes designed from the flanking sequences of the microsatellite markers (Table 1). The 40 mers were end-labeled with ${ }^{32} \mathrm{P} \gamma \mathrm{ATP}$ using T4 polynucleotide kinase and hybridized to six BAC filters at a time as described by Johnstone et al. (2008). Briefly, prehybridization was carried out in $5 \times$ salinesodium citrate buffer (SSC), $0.5 \%$ sodium dodecyl sulfate (SDS), and $5 \times$ Denhardt's solution at $65^{\circ} \mathrm{C}$ for $3 \mathrm{~h}$, and then the ${ }^{32} \mathrm{P}$-labeled probes were added and incubated overnight. The filters were washed three times, each for $1 \mathrm{~h}$ at $50^{\circ} \mathrm{C}$ in $1 \times \mathrm{SSC}$ and $0.1 \% \mathrm{SDS}$. The filters were wrapped in Saran $^{\mathrm{TM}}$ wrap and exposed to phosphor screens that were 
Table 1 Oligonucleotide probes and primers used for screening the Atlantic salmon BAC library

The oligonucleotide probe also acted as one of the PCR primer pairs for checking the hybridization-positive BACs

\begin{tabular}{ll}
\hline Primer names & Nucleotide sequences \\
\hline BHMS130F and probe & AAAACACTCTAATGGTTGTGTCAGTCAGAGACAACCCTCC \\
BHMS130R & TGTCAGTCTGCTAAACACTG \\
BHMS177F and probe & TTATCTGGGATCACTGATTAGAGCTGTTCATCTGGCTGTG \\
BHMS177R & CTTTCCATTTCCTCCCCCAG \\
BHMS553R and probe & GAGTGCTAACTTCAAGGCTTCTCCACTAATAGTCTGAAGG \\
BHMS553F & CTGTAAACATCACAGGCG \\
Ssa0130ECIGF and probe & CAGTTAGGTGAGGGGGTTAGGGGAAAATGTCAAGGCAAAG \\
Ssa0130ECIGR & GGACACACCTACTCATTCCA \\
Ssa0821BSFUF & TAACGAATGACAGCTTGCTA \\
Ssa0821BSFUR & AGCCTTTTTCAAAGAATGTG \\
S0076B01T7F and probe & GTAGTGGGACTCAGGTGGTATGCTATTTCCCTTCCCAATA \\
S0076B01T7R & GTACAGACTGTGGGTTGAGG \\
Ssa0578BSFUF & TTGAAACCCTTTCTGTGATT \\
Ssa0578BSFUR & CTGACTCTGGCATGTACAAA \\
\hline
\end{tabular}

subsequently scanned using the Typhoon Imaging System and visualized using ImageQuant software, giving an image of the ${ }^{32} \mathrm{P}$-labeled hybridization-positive BACs containing the microsatellite markers. The hybridization-positive BAC clones were picked from the library, cultured in $5 \mathrm{~mL} \mathrm{LB}$ media containing chloramphenicol $(50 \mu \mathrm{g} / \mathrm{mL})$ overnight at $37^{\circ} \mathrm{C}$ shaking at $250 \mathrm{rpm}$, and made into glycerol stocks for subsequent polymerase chain reaction (PCR) verification that they did indeed contain the appropriate microsatellite marker. The PCR reaction mixture contained $1 \mu \mathrm{L}$ of $10 \times$ PCR buffer containing $\mathrm{MgCl}_{2}$ (QIAGEN), $1 \mu \mathrm{L}$ of $2 \mathrm{mM}$ dNTPs, $0.5 \mu \mathrm{L}$ of $10 \mu \mathrm{M} 40$-mer probe, $0.5 \mu \mathrm{L}$ of $10 \mu \mathrm{M}$ complementary primer, $0.15 \mu \mathrm{L}$ of Taq DNA polymerase (QIAGEN), and $6.8 \mu \mathrm{L}$ of $\mathrm{dH}_{2} \mathrm{O}$. A small amount of BAC clone glycerol stock was added into the PCR reaction mix as template. The PCR conditions comprised $95^{\circ} \mathrm{C}$ for $5 \mathrm{~min}$ followed by 35 cycles of $95^{\circ} \mathrm{C}$ for $45 \mathrm{~s}, 65^{\circ} \mathrm{C}$ for $45 \mathrm{~s}$ and $72^{\circ} \mathrm{C}$ for $2 \mathrm{~min}$, and then $72^{\circ} \mathrm{C}$ for $10 \mathrm{~min}$. PCR products were separated by electrophoresis through a $1.3 \%$ agarose gel with $1 \times$ TAE, stained with ethidium bromide, and visualized using a UV trans-illuminator (Alpha Innotech). Hybridization and PCR-positive BACs for the microsatellite markers were matched to fingerprint contigs within the Atlantic salmon physical map (Ng et al. 2005 as shown on www.asalbase.org).

Construction of Minimum Tiling Paths for BAC Contigs and Chromosome Walking

The construction of minimum tiling paths for fingerprint contigs followed the procedure outlined in Quinn et al. (2008). The approach to probe and primer design for chromosome walking was as described above except that the program used was Primer3 Input (version 0.4.0; http:// frodo.wi.mit.edu/primer3/) instead of OLIGO 4.0. The probes and corresponding complementary primers were designed to produce a PCR product of approximately 200 bp. BAC library screening and PCR testing for confirmation of true positives followed the procedure described above. Two fingerprint contigs were considered joined if a BAC from one contig was confirmed to be a true positive of a probe from another contig.

\section{Linkage Mapping}

Linkage analysis was carried out using the two Atlantic salmon SALMAP mapping families as previously described (Danzmann et al. 2008; Phillips et al. 2009). The most recent version of the merged female Atlantic salmon genetic map can be seen on www.asalbase.org.

\section{Comparative Genome Analysis}

A freely accessible Web-based database, ASalBase (www. asalbase.org), has been built to display the Atlantic salmon linkage map, physical map, and associated information such as BAC end sequences (Boroevich et al. 2008). This website provides a rich resource for comparative genomic analysis using the Atlantic salmon BAC end sequences. BAC end sequences $(207,869)$ with an average length of 666 bp ( $3.5 \%$ of the genome) are shown on this site. After masking the BAC end sequences using the Repeat Masker program on the University of Victoria cGRASP website (http://lucy.ceh.uvic.ca/repeatmasker/cbr_repeatmasker.py), they were subjected to a BLASTx sequence similarity search against the tetraodon, medaka, stickleback, and zebrafish (Ensembl release 53 protein databases). These comparisons enabled us to identify putative regions of the genomes of these four fish that are syntenic with the Atlantic salmon ISA QTL region. 


\section{Results and Discussion}

Identification of BACs Containing the Genetic Markers Associated with the ISA Resistance QTL

The results from QTL mapping of ISA resistance in Atlantic salmon identified three microsatellite markers, BHMS177, BHMS553, and BHMS130, most closely associated with this trait (Moen et al. 2007). These microsatellites are tightly linked spanning, approximately $4.3 \mathrm{cM}$ from 30.4 to $34.7 \mathrm{cM}$ on $\mathrm{Chr} 15$ of the integrated female map (Phillips et al. 2009; www.asalbase.org). We noted that the marker Ssa0130ECIG also mapped to this region. We designed oligonucleotide probes from the flanking regions of these four microsatellite markers (Table 1) and used them to screen the CHORI-214 Atlantic salmon BAC library (Thorsen et al. 2005). The hybridization-positive BACs were examined by PCR using the primers that amplify the four microsatellite markers (Table 1). BACs which gave amplification products of the expected size are listed in Table 2 along with the four

Table 2 BACs, and the contigs to which they have been assigned ( $\mathrm{Ng}$ et al. 2005), that were positive by hybridization and PCR confirmation for genetic markers in the Atlantic salmon ISA QTL region (Moen et al. 2007)

\begin{tabular}{|c|c|c|}
\hline Markers & Positive BACs & Contig \\
\hline \multirow[t]{4}{*}{ BHMS130 } & S0019O02 & 1180 \\
\hline & S0026I01 & 1180 \\
\hline & $\mathrm{S} 0123 \mathrm{H} 01$ & 1180 \\
\hline & S0006L24 & Singleton \\
\hline \multirow[t]{2}{*}{ BHMS553 } & S0036K05 & 386 \\
\hline & S0045L14 & 386 \\
\hline BHMS177 & S0353K21 & 1907 \\
\hline \multirow[t]{8}{*}{ Ssa130ECIG } & S0819015 & 620 \\
\hline & S0835A07 & 620 \\
\hline & S0848I03 & 620 \\
\hline & S0881C19 & 620 \\
\hline & S0927L15 & 620 \\
\hline & S0933B05 & 620 \\
\hline & S0941O10 & 620 \\
\hline & S0958C23 & Not fingerprinted \\
\hline Ssa0821BSFU & S0092G24 & 620 \\
\hline \multirow[t]{7}{*}{ S0076B01T7 } & S0076B01 & 620 \\
\hline & S0143G23 & 1907 \\
\hline & S0228D13 & 1907 \\
\hline & S0824B12 & 1907 \\
\hline & $\mathrm{S} 0928 \mathrm{O} 23$ & 1907 \\
\hline & S0939C19 & Not fingerprinted \\
\hline & S0960I24 & Not fingerprinted \\
\hline Ssa0578BSFU & $\mathrm{S} 0038 \mathrm{H} 22$ & 227 \\
\hline
\end{tabular}

fingerprint contigs of the physical map ( $\mathrm{Ng}$ et al. 2005; www.asalbase.org) to which they belong, namely, contigs $1180,386,1907$, and 620 . Contig 620 contains a microsatellite marker, Ssa0821BSFU, derived from a BAC end sequence. Ssa0812BSFU was mapped in the Atlantic salmon SALMAP mapping families (Danzmann et al. 2008) to Atlantic salmon Chr15 at position $30.4 \mathrm{cM}$ of the integrated female map, which is consistent with the mapping of the other markers listed above.

Construction of Minimum Tiling Paths and Chromosome Walking in the ISA Resistance QTL Genomic Region

We made use of the extensive $\mathrm{BAC}$ end sequence database and designed PCR primers from BACs in contigs 1180 , 386,1907 , and 620 . This allowed us to construct minimum tiling paths for these contigs. We then attempted to carry out chromosome walking by screening the BAC library with oligonucleotide probes designed from $\mathrm{BAC}$ end sequences of BACs that were at the ends of the contigs. This proved very difficult, primarily because of the repetitive nature of the Atlantic salmon genome (de Boer et al. 2007); however, the probe derived from the T7 end sequence of BAC S0076B01, which is in contig 620, hybridized to several BACs from contig 1907 (Table 2), indicating that contigs 620 and 1907 overlap one another. When we examined the putative syntenic regions of these four contigs on the medaka genome using www.asalbase. org, we noted that contig 227 was adjacent to contig 1907. Contig 227 contains the BAC end sequence-derived genetic marker Ssa0578BSFU. Using the Atlantic salmon SALMAP mapping families, we mapped Ssa0578BSFU to $34.7 \mathrm{cM}$ on Chr15, which is at one end of the ISA resistance QTL region.

\section{Comparative Genomic Analyses}

We used the BAC end sequences from contigs 1180, 386, 1907, 620, and 227 to carry out similarity searches against the genomic sequences of tetraodon ( $T$. nigroviridis), medaka (O. latipes), stickleback (Gasterosteus aculeatus), and zebrafish (D. rerio) (Ensembl release 53). Table 3 provides a summary of the results. It appears that this region of Chr15 in Atlantic salmon shares extensive synteny with LG14 of tetraodon, LG24 of medaka, LGXVIII of stickleback, and LG20 of zebrafish. It should be noted that in the comparisons of Atlantic salmon with tetraodon, medaka, and stickleback, there appears to be a discontinuity between contigs 227 and 1180, although the linkage group is conserved in all cases. This is illustrated for medaka in Fig. 1. Similarly, the comparison of the Atlantic salmon and zebrafish suggests that some rearrangements have occurred in these genomes, but their nature is 
Table 3 Regions of fish genomes that are syntenic to the ISA QTL in Atlantic salmon based on similarity searches using the BAC end sequences from contigs that contain genetic markers associated with ISA resistance (Moen et al. 2007)

\begin{tabular}{lcccccc}
\hline ISA QTL markers & Map position & Contig & Tetraodon LG14 & Medaka LG24 & Stickleback LGXVIII & Zebrafish LG20 \\
\hline BHMS553 & 30.4 & 386 & $9,450 \mathrm{k}-9,550 \mathrm{k}$ & $15,600 \mathrm{k}-16,400 \mathrm{k}$ & $13,200 \mathrm{k}-13,300 \mathrm{k}$ & $39,500 \mathrm{k}-40,500 \mathrm{k}$ \\
BHMS177 & 30.4 & 1907 & $9,550 \mathrm{k}-10,000 \mathrm{k}$ & $15,600 \mathrm{k}-16,400 \mathrm{k}$ & $15,800 \mathrm{k}-15,900 \mathrm{k}$ & $29,700 \mathrm{k}-30,000 \mathrm{k}$ \\
Ssa0130ECIG & 30.4 & 620 & $9,970 \mathrm{k}-10,000 \mathrm{k}$ & $23,300 \mathrm{k}-23,900 \mathrm{k}$ & $12,700 \mathrm{k}-12,800 \mathrm{k}$ & $29,500 \mathrm{k}-30,000 \mathrm{k}$ \\
Ssa0821BSFU & 30.4 & 620 & $9,970 \mathrm{k}-10,000 \mathrm{k}$ & $23,300 \mathrm{k}-23,900 \mathrm{k}$ & $12,700 \mathrm{k}-12,800 \mathrm{k}$ & $29,500 \mathrm{k}-30,000 \mathrm{k}$ \\
Ssa0578BSFU & 34.7 & 227 & $10,200 \mathrm{k}-10,250 \mathrm{k}$ & $23,700 \mathrm{k}-24,400 \mathrm{k}$ & $16,000 \mathrm{k}-16,100 \mathrm{k}$ & $26,200 \mathrm{k}-26,300 \mathrm{k}$ \\
BHMS130 & 34.7 & 1180 & $8,350 \mathrm{k}-8,400 \mathrm{k}$ & $2,700 \mathrm{k}-3,200 \mathrm{k}$ & $2,500 \mathrm{k}-2,530 \mathrm{k}$ & $56,400 \mathrm{k}-56,600 \mathrm{k}$ \\
\hline
\end{tabular}

not immediately obvious. Another possibility is that the resolution of the linkage map is imprecise because of the nature of the SALMAP mapping families used for its construction (see Danzmann et al. 2008 for details). However, it was both reassuring and satisfying to discover that there is an apparent conservation of synteny among all of these phylogenetically diverse fish genomes corresponding to this segment of Chr15 in Atlantic salmon. Tetraodon has one of the most compact vertebrate genomes (Jaillon et al. 2004), and therefore, we decided to examine the region from $8,350 \mathrm{k}$ to $10,250 \mathrm{k}$ in tetraodon LG14 in more detail. We also examined the region from $15,600 \mathrm{k}$ to $23,900 \mathrm{k}$ in medaka LG24. We developed gene lists from these regions of the tetraodon and medaka genomes using the BioMart tool from Ensembl (Electronic Supplementary Material Tables 1 and 2). We expected that these lists would contain one or more orthologs of candidate genes that could explain the ISA resistance in Atlantic salmon.
Comparison of QTL Gene Lists with Microarray Gene Expression Lists from ISA-Infected and Uninfected Atlantic Salmon

Several studies have examined the changes in gene expression in Atlantic salmon tissues and cultured salmon cells that result from exposure to ISA (Jørgensen et al. 2007, 2008; Kiling et al. 2007; McBeath et al. 2007; Schiøtz et al. 2008; Workenhe et al. 2008, 2009). Although we considered the results from all of these publications, we concentrated on the recent work of Workenhe et al. (2009). Our rationale was that this study used the most comprehensive microarray (i.e., the cGRASP 16,000 cDNA array described by von Schalburg et al. 2008) to examine the changes that occur in the macrophage/dendritic-like cell line TO infected with a either a low pathogenic or a highly pathogenic strain of ISA at 24 and $72 \mathrm{~h}$ post infection. We first compared the complete catalog of differentially
Fig.1 Schematic representation of the genetic map of Atlantic salmon Chr15 (LG8) showing the ISA QTL region identified by Moen et al. (2004a, 2007) and the corresponding syntenic regions of medaka LG24

\section{Atlantic salmon Chr15}

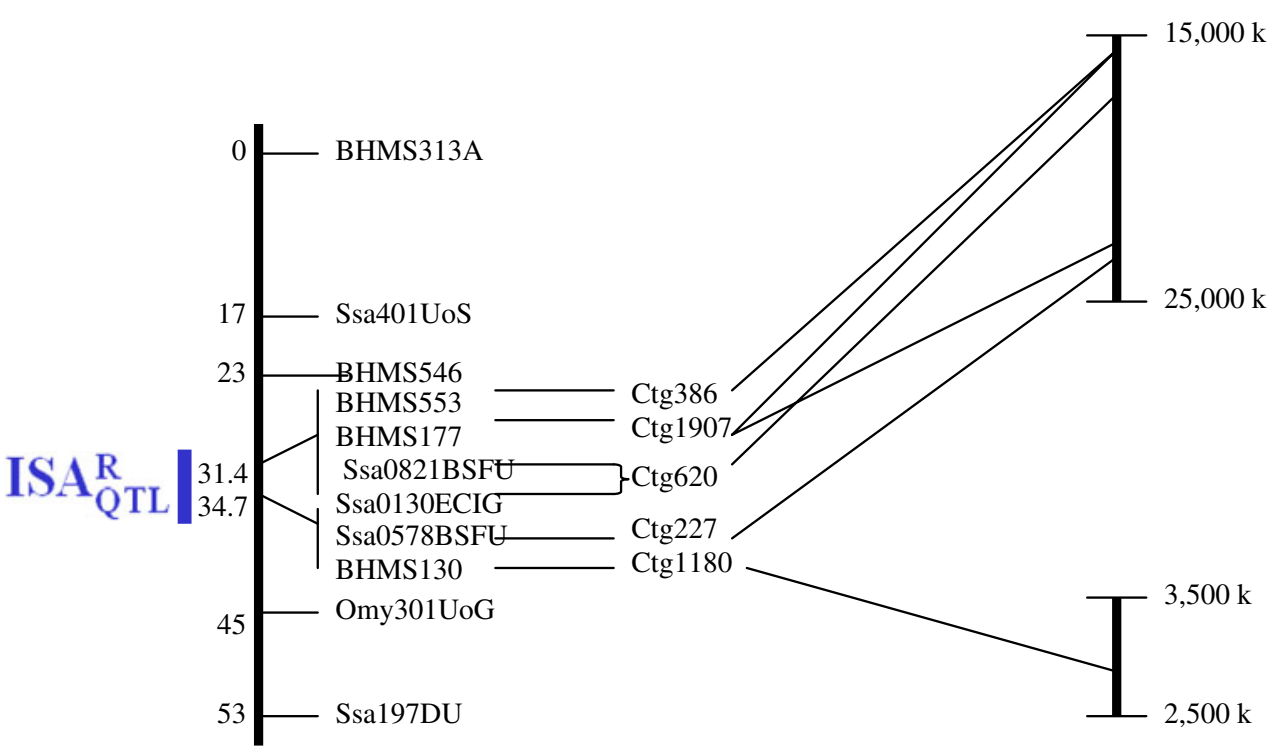

Medaka LG24

Unit= centi-Morgan 
regulated genes (Workenhe et al. 2009) with the list of genes in the ISA resistance QTL putative syntenic region of the tetraodon genome (LG14 position $8,350 \mathrm{k}-10,250 \mathrm{k}$ ) as well as the corresponding region in the medaka genome from $15,600 \mathrm{k}-24,400 \mathrm{k}$ on LG24. The annotation of fish genomes as well as the cDNAs on the cGRASP microarray is an imprecise science as it is based on sequence similarities primarily with mammalian genes. This is further complicated by the relatively recent genome duplication in the common ancestor of extant salmonids (Allendorf and Thorgaard 1984). We therefore took a very liberal approach when making our comparisons. For example, we considered galectin-3 and galectin- 8 as being potential orthologs of galectin- 9 and included proteasome subunits irrespective of them being classified as alpha or beta. The results of this comparison are shown in Table 4. The tetraodon comparisons revealed 14 annotated genes that had a putative ortholog identified as being differentially expressed from the microarray experiments. These included four genes classified as E3 ubiquitin-protein ligases (RNF8, RNF19B, RNF217, and UBR7), three $N$-acetyl transferases (ESCO2, NAT12, and NAT5), two tripartite motif-containing genes (TRIM54 and TRIM67), two galectins (LGALS3 and LGALS8), a single copy of a tetratricopeptide repeat protein (TTC13), and two members of the proteasome (26S protease regulatory subunit 4, PSMC1, and proteasome subunit alpha type-6, PROS-27). We note that galectin-9 was one of the four genes, along with 5lipoxygenase activating protein, cytochrome P450 2K4-I, and annexin AI, which were sufficient for correct assignment of individual salmon to early mortality, late mortality, and uninfected groups (Jørgensen et al. 2008). Only three of the 14 genes from the tetraodon selected gene list were annotated in the corresponding region of the medaka genome: TTC13, RNF217, and NAT5. The transcript corresponding to TTC13 was increased 26.88 -fold and 30.24 fold in TO cells infected with ISA at the 24 and 72-h post-infection time points, respectively. In contrast, there was no significant increase in the abundance of RNF217 transcripts in the TO cells after $24 \mathrm{~h}$ of infection, but it rose 16.61-fold over that found in the control after $72 \mathrm{~h}$ of infection. The change in expression of NAT5 was only observed in TO cells $72 \mathrm{~h}$ post infection with the highly pathogenic ISAV isolate. We suggest that the genes listed in Table 4, particularly TTC13, RNF217, and NAT5, are worthy of further consideration as potential candidates that could contain alleles that are causal for the ISA resistance QTL. Furthermore, we suggest that they be screened for polymorphisms that alter their expression pattern as well as cause changes in their protein products.

Prediction of Candidate Genes for the ISA Resistance QTL Based on Putative Functions of Their Protein Products

It is widely recognized that interferons and the products of the genes they induce play a critical part in the innate immunity system against viruses. Although more than 100 interferon-stimulated genes have been identified, to date,

Table 4 Genes, previously identified as being differentially expressed in ISA-infected salmon by microarray analysis from Workenhe et al. (2009), that are annotated in the ISA QTL syntenic regions of the medaka and tetraodon genomes (Electronic Supplementary Material Tables 1 and 2, respectively)

\begin{tabular}{|c|c|c|c|c|}
\hline Common name & Tetraodon gene & Medaka gene & $\begin{array}{l}\text { Fold increase at } \\
24 \mathrm{~h} \text { post infection }\end{array}$ & $\begin{array}{l}\text { Fold increase at } \\
72 \mathrm{~h} \text { post infection }\end{array}$ \\
\hline$N$-acetyltransferase $(\mathrm{ESCO} 2)^{\mathrm{a}}$ & $\mathrm{ESCO} 2$ & Not annotated & Not significant & $3.47^{\mathrm{f}}$ \\
\hline Tripartite motif-containing protein 67 (TRIM9-like protein) ${ }^{\mathrm{b}}$ & TRIM67 & Not annotated & $3.67-4.83$ & $5.40-14.4 .1$ \\
\hline Tetratricopeptide repeat protein 13 & TTC13 & TTC13 & 26.88 & 30.24 \\
\hline E3 ubiquitin-protein ligase (RING finger protein 8$)^{\mathrm{c}}$ & RNF8 & Not annotated & Not significant & 16.61 \\
\hline E3 ubiquitin-protein ligase (RING finger protein $19 \mathrm{~B})^{\mathrm{c}}$ & RNF19B & Not annotated & Not significant & 16.61 \\
\hline E3 ubiquitin-protein ligase (RING finger protein 217$)^{\mathrm{c}}$ & RNF217 & RNF217 & Not significant & 16.61 \\
\hline$N$-acetyltransferase $12^{\mathrm{a}}$ & NAT12 & Not annotated & Not significant & $3.47^{\mathrm{f}}$ \\
\hline Galectin-3 (GALBP) $^{\mathrm{d}}$ & LGALS3 & Not annotated & $2.76-6.01^{\mathrm{d}}$ & $37.09-167.22$ \\
\hline Galectin-8 (Gal-8; PCTA-1) ${ }^{\mathrm{d}}$ & LGALS8 & Not annotated & $2.76-6.01^{\mathrm{d}}$ & $37.09-167.22$ \\
\hline $26 \mathrm{~S}$ protease regulatory subunit $4(\mathrm{P} 26 \mathrm{~s} 4 \text { ATPase } 1)^{\mathrm{e}}$ & PSMC1 & Not annotated & Not significant & 25.41 \\
\hline Proteasome subunit alpha type-6 (PROS-27) ${ }^{\mathrm{e}}$ & PSMA $^{\mathrm{b}}$ & Not annotated & Not significant & $3.42-4.52$ \\
\hline Tripartite motif-containing protein 54 (MURF-3) ${ }^{\mathrm{b}}$ & TRIM54 & Not annotated & $3.67-4.83$ & $5.40-14.4 .1$ \\
\hline$N$-acetyltransferase $5^{\text {a }}$ & NAT5 & NAT5 & Not significant & $3.47^{\mathrm{f}}$ \\
\hline E3 ubiquitin-protein ligase UBR7 (N-recognin-7) ${ }^{\mathrm{c}}$ & UBR7 & Not annotated & Not significant & 16.61 \\
\hline
\end{tabular}

The genes are listed in the order in which they occur in the tetraodon genome. Genes encoding proteins with the same function are identified by the same superscript. We took a very liberal approach with annotation comparisons (e.g., we took galectin-3 and galectin- 8 as being a potential homolog of galectin-9 and proteasome subunits irrespective of them being alpha or beta). The fold increase results are with infection with a low pathogenic ISAV isolate (RPC/NB-04-085-1) except for ${ }^{\mathrm{f}} \mathrm{N}$-acetyltransferase at $72 \mathrm{~h}$ post infection with a highly pathogenic ISAV isolate (NBISA01) 
Mx is the only one that has been shown to possess antiviral properties (Haller et al. 2007; Robertsen 2008). It has been shown that ISA is a powerful inducer of key genes of the type I interferon system in Atlantic salmon, including $\mathrm{Mx}$, but the virus is not inhibited by the interferon-dependent pathway or the presence of Mx prior to infection (Kiling et al. 2007). Therefore, we considered what is known about resistance to viruses in other systems and if this information could be applied to identifying candidate genes for ISA resistance in Atlantic salmon. Several genes have been identified with allelic variation that influences HIV infection and disease progression (Heeney et al. 2006). Among these are the tripartite motif-containing protein TRIM $5 \alpha$; cytokines such as IL-10; coreceptor/ligands such as CCR5, CCL2, CCL7, CCL11, and DC-SIGN; and components of the adaptive immune response, namely, subtypes of HLAA, HLA-B, and HLA-C. Similarly, it has recently been shown that the host genetic background strongly influences the response of influenza A virus infections in mice, although the molecular basis for this phenomenon has yet to be identified (Srivastava et al. 2009). As indicated in the review article by Beutler et al. (2007), it is quite feasible to consider mutations arising in the host that confer virus resistance by affecting some of the key steps in viral entry into a cell, its replication, and ultimately its assembly and spread to other cells. In the case of ISA resistance in Atlantic salmon, it is possible that the allele(s) associated with the QTL is in a gene(s) that is not directly involved in the interferon response pathways. Moreover, a significant change in the expression of the gene may not be required for the effect to be realized. Therefore, we searched the BioMart gene lists from the ISA resistance QTL putative syntenic regions of the tetraodon and medaka genomes and identified some potentially interesting genes whose products have been discussed in the context of naturally occurring mutations associated with viral resistance (Heeney et al. 2006; Beutler et al. 2007). The list of seven potential ISA resistance candidate genes we wish to consider is given in Table 5.

HDDC2 (NS5A-TP2) is an HD domain-containing protein that is induced by the non-structural 5A (NS5A) protein of hepatitis $\mathrm{C}$ virus (Yang et al. 2004). The hepatitis $\mathrm{C}$ virus NS5A plays multiple roles in virus infection including viral replication and cellular signaling pathways (see MacDonald and Harris 2004 for review). It has been suggested that hepatitis $\mathrm{C}$ virus resistance to interferon could be explained by the ability of NS5A to bind to and inhibit the dsRNA-activated, interferon-induced kinase PKR (Gale et al. 1997). We speculate that variation in proteins that are induced by NS5A, or its equivalent in other single-stranded RNA viruses such as ISA, may be associated with differential responses to viral infection, and thus, HDDC2 (NS5A-TP2) becomes a candidate for the Atlantic salmon ISA resistance QTL.

Toll/interleukin-1 receptor-like protein 5 (TLR5) is a member of the Toll-like receptor (TLR) family (Akira et al. 2006). Recognition of specific ligands by TLRs induces MyD88-dependent signaling via the Toll-IL-1 receptor pathways, which activate dendritic cells and help induce their differentiation into antigen presenting cells (Takeda et al. 2003). Single-stranded RNA serves as a physiological ligand for TLR7 and TLR8 (Heil et al. 2004; Diebold et al. 2004). TLR5 is generally thought to be involved in flagellated bacterial pathogen detection (Hayashi et al. 2001), and a novel transcript encoding a soluble form of TLR5 was observed in the liver of Atlantic salmon during Aeromonas salmonicida infection (Tsoi et al. 2007). We speculate that a variant of TLR5 in Atlantic salmon may have become a ligand for ISAV and that this could explain the ISA resistance QTL that occurs in Atlantic salmon.

HIV-EP2 is a member of the metal-finger protein family that binds to the human immunodeficiency virus type 1 enhancer (Nomura et al. 1991). HIV-EP2 is expressed at high levels in $\mathrm{T}$ cells, and its expression is induced by

Table 5 Candidate genes for ISA resistance in the QTL syntenic regions of the tetraodon and medaka genomes based on the predicted functions of gene products

\begin{tabular}{|c|c|c|}
\hline Common gene name & Tetraodon gene & Medaka gene \\
\hline $\begin{array}{l}\text { HD domain-containing protein } 2 \text { (hepatitis } \mathrm{C} \text { virus } \\
\text { NS5A-transactivated protein } 2 \text { ) }\end{array}$ & HDDC2 & HDDC2 \\
\hline $\begin{array}{l}\text { Toll-like receptor } 5 \text { Precursor (Toll/interleukin-1 } \\
\text { receptor-like protein 3) }\end{array}$ & TLR5 & TLR5 \\
\hline $\begin{array}{l}\text { Transcription factor HIVEP2 (HIV-EP2; MHC-binding } \\
\text { protein 2)(MBP-2)) }\end{array}$ & HIVEP2 & HIVEP2 \\
\hline Interleukin-1 receptor-associated kinase 1-binding protein 1 & IRAK1BP1 & Not annotated in syntenic region \\
\hline $\begin{array}{l}\text { NF-kappa-B inhibitor alpha (MHC complex enhancer-binding } \\
\text { protein MAD3) }\end{array}$ & NFKBIA & Not annotated in syntenic region \\
\hline Feline leukemia virus subgroup $\mathrm{C}$ receptor-related protein 1 & FLVCR1 & Not annotated in syntenic region \\
\hline $\begin{array}{l}\text { Interleukin-20 receptor alpha chain Precursor } \\
\text { (cytokine receptor class-II member } 8 \text { ) }\end{array}$ & Not annotated in syntenic region & IL20RA \\
\hline
\end{tabular}


mitogen and phorbol ester treatment, suggesting that it is involved in the regulation of $\mathrm{T}$ cell growth. The transcription factor HIV-EP2 also binds to the enhancer of the major histocompatibility complex (MHC) class I genes, and thus, it is also known as MHC-binding protein 2 (MBP-2; van't Veer et al. 1992). Related enhancer motifs to those of MHC and HIV occur in the regulatory regions of immunoglobulin genes, the $\beta_{2}$ microglobulin gene, the interferon $\beta$ gene, and the interleukin 2 receptor gene. Therefore, changes in the structure of HIV-EP2/MBP-2 may influence the expression of several genes that have been implicated in the response to infection by ISAV. It is noteworthy that three of the microsatellite markers associated with the ISA resistance QTL (BHMS177, Ssa0821BSFU, and Ssa0130CIG) map to the syntenic region in the medaka genome where HIV-EP2/MBP-2 occurs (Fig. 2). We suggest that HIV-EP2/MBP-2 is a very strong candidate for the gene associated with ISAV resistance in Atlantic salmon and that it is definitely worthy of further study.

Complex signaling pathways link the recognition of pathogens by TLRs and the activation of the transcription factor NF-K $\beta$ which regulates the expression of genes essential for host defense and inflammation (Akira et al. 2006). We identified two genes in the Atlantic salmon ISA resistance QTL syntenic region of the tetraodon genome that are part of the NF- $\mathrm{k} \beta$ regulatory pathway, namely, interleukin receptor-associated kinase 1 binding protein 1 (IRAK1BP1) and NF-K $\beta$ inhibitor alpha (NFKBIA; Li and
Verma 2002). We suggest that allelic variation in one of these genes that are involved in modulating the NF-K $\beta$ signaling pathway could be responsible for variation in ISA resistance in Atlantic salmon. Thus, they are worthy of further investigation.

As mentioned above, it is possible that a mutation in Atlantic salmon could confer ISA resistance by affecting a key step in viral entry into a cell. It was interesting, therefore, to find feline leukemia virus subgroup $\mathrm{C}$ receptor-related protein 1 (FLVCR1) in the ISA resistance QTL syntenic region of the tetraodon genome. The preferred receptor for the feline leukemia virus subgroup $\mathrm{C}$, a $\gamma$-retrovirus, is a transporter involved in the export of heme (Tailor et al. 2003). We speculate that mutations in the Atlantic salmon FLVCR1 ortholog may be associated with ISA resistance.

The final gene that we identified as a possible candidate associated with the ISA resistance QTL in Atlantic salmon is interleukin-20 receptor alpha chain (IL20RA), which was observed in the ISA resistance QTL syntenic region of the medaka genome but not in the corresponding region of the tetraodon genome. IL20RA encodes one of the heterodimers of the IL-20R complex through which Signal Transducer and Activator of Transcription activation occurs when bound to IL-19, IL-20, or mda-7 (Dumoutier et al. 2001). We speculate that signaling through the IL-20R complex may provide an alternative mechanism for activating a host defense against ISA in Atlantic salmon.



Fig. 2 A screenshot from www.asalbase.org that shows the annotated genes and transcripts from $23,300 \mathrm{k}-23,900 \mathrm{k}$ of medaka LG24 as well as the Atlantic salmon BAC end sequences that align with them. This region also contains one of the microsatellites, BHMS177, associated with the ISA resistance QTL (Moen et al. 2007) and three additional markers, Ssa0821BSFU, Ssa0130ECIG, and Ssa0578BSFU, that are tightly linked to BHMS177 (Danzmann et al. 2008; Phillips et al. 2009) 


\section{Conclusions}

In the absence of a sequence for the Atlantic salmon genome, we have taken a comparative genomics approach to identify candidate genes that may be associated with the QTL for ISA that has been mapped to Chr 15 (Moen et al. 2004a, 2007). We recognize that we have indulged in broad speculation in developing the list of candidate genes given in Tables 4 and 5 but wish to point out that even when a well-annotated genomic sequence becomes available for Atlantic salmon, it will still be necessary to identify candidate genes based on their putative physiological functions and to test them in ISAresistant and susceptible families. Of course, having a sequence of the Atlantic salmon genome should provide additional genetic markers, which would allow finer mapping of the QTL.

Acknowledgments Funding for this work was provided by Genome Canada, Genome British Columbia, and NSERC. We thank Evelyn Davidson and Krzysztof Lubieniecki for the help with genotyping.

Open Access This article is distributed under the terms of the Creative Commons Attribution Noncommercial License which permits any noncommercial use, distribution, and reproduction in any medium, provided the original author(s) and source are credited.

\section{References}

Adzhubei AA, Vlasov AV, Hagen-Larsen H, Ruden TA, Laerdahl JK, Høyheim B (2007) Annotated Expressed Sequence Tags (ESTs) from pre-smolt Atlantic salmon (Salmo salar) in a searchable data resource. BMC Genomics 8:209

Akira S, Uematsu S, Takeuchi O (2006) Pathogen recognition and innate immunity. Cell 124:783-801

Allendorf FW, Thorgaard GH (1984) Tetraploidy and the evolution of salmonids fishes. In: Turner BJ (ed) Evolutionary genetics of fishes. Plenum Press, New York, pp 55-93

Beutler B, Eidenschenk C, Crozat K, Imler J-L, Takeuchi O, Hoffmann JA, Akira S (2007) Genetic analysis of resistance to viral infection. Nature Rev Immunol 7:753-766

Boroevich KA, Lubieniecki KP, Chow W, de Jong P, Schein J, Field M, Moore R, de Boer JG, Koop BF, Davidson WS (2008) Physical mapping and BAC-end sequence analysis of Atlantic salmon BAC libraries. In: W282: large-insert DNA libraries and their applications. Plant \& Animal Genomes XVI Conference (W282), San Diego, CA, 12-16 Jan 2008

Danzmann RG, Davidson EA, Ferguson MM, Gharbi K, Koop BF, Hoyheim B, Lien S, Lubieniecki KP, Moghadam HK, Park J, Phillips RB, Davidson WS (2008) Distribution of ancestral protoActinopterygian chromosome arms within the genomes of $4 \mathrm{R}$ derivative salmonid fishes (Rainbow trout and Atlantic salmon). BMC Genomics 9:557

de Boer JG, Yazawa R, Davidson WS, Koop BF (2007) Bursts and horiozontal evolution of DNA transposons in the speciation of pseudotetraploid salmonids. BMC Genomics 8:422

Diebold SS, Tsuneyasu K, Hemmi H, Akira S, Reis e Sousa C (2004) Innate antiviral responses by means of TLR7-mediated recognition of single-stranded RNA. Science 303:1529-1531
Dumoutier L, Leemans C, Lejeune D, Kotenko SV, Renauld J-C (2001) Stat activation by IL-19, IL-20 and mda-7 through IL-20 receptors of two types. J Immunol 167:3545-3549

Eliassen TM, Froystad MK, Dannevig BH, Jankowska M, Brech A, Falk K, Romoren K, Gjoen T (2000) Initial events in infectious salmon anemia virus infection: evidence for the requirement of a low-pH step. J Virol 74:218-227

Falk K, Namork E, Rimstad E, Mjaaland S, Dannevig BH (1997) Characterization of infectious salmon anemia virus, an orthomyxo-like virus isolated from Atlantic salmon (Salmo salar L.). J Virol 71:9016-9023

Falk K, Aspehaug V, Vlasak R, Endresen C (2004) Identification and characterization of viral structural proteins of infectious salmon anemia virus. J Virol 78:3063-3071

Gale MJ, Korth MJ, Tang NM, Tan SL, Hopkins DA, Dever TE, Polyak SJ, Gretch DR, Katze MG (1997) Evidence that hepatitis $\mathrm{C}$ virus resistance to interferon is mediated through repression of the PKR protein kinase by the nonstructural 5A protein. Virology 230:217-227

Gjoen HM, Refstie T, Ulla O, Gjerde B (1997) Genetic correlations between survival of Atlantic salmon in challenge and field tests. Aquaculture 158:277-288

Godoy MG, Aedo A, Kibenge MJ, Groman DB, Yason CV, Grothusen $\mathrm{H}$, Lisperguer A, Calbucura M, Avendanio F, Imilan M, Jarpa M, Kibenge FS (2008) First detection, isolation and molecular characterization of infectious salmon anemia virus associated with clinical disease in farmed Atlantic salmon (Salmo salar) in Chile. BMC Vet Res 4:28

Gross JB, Protas M, Conrad M, Scheid PE, Vidal O, Jeffrey WR, Borowsky R, Tabin CJ (2008) Synteny and candidate gene prediction using an anchored linkage map of Astyanax mexicanus. Proc Natl Acad Sci USA 105:20106-20111

Haller O, Staeheli P, Kochs G (2007) Interferon-induced Mx proteins in antiviral host defense. Biochemie 89:812-818

Hayashi F, Smith KD, Ozinsky A, Hawn TR, Yi EC, Godltt DR, Eng JK, Akira S, Underhill DM, Anderem A (2001) The innate immune response to bacterial flagellin is mediated by Toll-like receptor 5. Nature 410:1099-1103

Heeney JL, Dalgleish AG, Weiss RA (2006) Origin of HIV and the evolution of resistance to AIDS. Science 313:462-466

Heil F, Hemmi H, Hochrein H, Ampenberger F, Kirschning C, Akira S, Lipford G, Wagner H, Bauer S (2004) Species-specific recognition of single-stranded RNA via Toll-like receptor 7 and 8. Science 303:1526-1529

Hellebo A, Vilas U, Falk K, Balzac R (2004) Infectious salmon anemia virus specifically binds and hydrolyzes 4-O-acetylated sialic acids. J Virol 78:3055-3062

Jaillon O, Aury JM, Brunet F et al (2004) Genome duplication in the teleost fish Tetraodon nigroviridis reveals the early vertebrate proto-karyotype. Nature 431:946-957

Johnstone KA, Lubieniecki KP, Chow W, Phillips RB, Koop BF, Davidson WS (2008) Genomic organization and characterization of two vomeronasal 1 receptor-like genes (ora1 and ora2) in Atlantic salmon Salmo salar. Mar Genomics 1:23-31

Jørgensen SM, Hetland DL, Press CM, Grimholt U, Gjøen T (2007) Effect of early infectious salmon anemia virus (ISAV) infection on expression of MHC pathway genes and type I and II interferon in Atlantic salmon (Salmo salar) tissues. Fish Shellfish Immunol 23:576-588

Jørgensen SM, Afanasyev S, Krasnov A (2008) Gene expression analyses in Atlantic salmon challenged with infectious salmon anemia virus reveal differences between individuals with early, intermediate and late mortality. BMC Genomics 9:179

Kibenge FSB, Munir K, Kibenge MJT, Joseph T, Moneke E (2004) Infectious salmon anemia virus: causative agent, pathogenesis and immunity. Anim Health Res Rev 5:65-78 
Kiling Ø, Brundtland MI, Robertsen B (2007) Infectious salmon anemia virus is a powerful inducer of key genes of the type I interferon system of Atlantic salmon, but is not inhibited by interferon. Fish Shellfish Immunol 23:378-389

Koop BF, von Schalburg KR, Leong J, Walker N, Lieph R, Cooper GA, Robb A, Beetz-Sargent M, Holt RA, Moore R, Brahmbhatt S, Rosner J, Rexroad CE III, McGowan CR, Davidson WS (2008) A salmonid EST genomic study: genes, duplications, phylogeny and microarrays. BMC Genomics 9:545

Krossoy B, Devold M, Sanders L, Knappskog PM, Aspehaug V, Falk K, Nylund A, Koumans S, Endresen C, Biering E (2001) Cloning and identification of the infectious salmon anemia haemagglutinin. J Gen Virol 82:1757-1765

Li Q, Verma IA (2002) NF-K $\beta$ regulation and the immune system. Nat Rev Immunol 2:725-734

Lorenz S, Brenna-Hansen S, Moen T, Roseth A, Davidson WS, Omholt SW, Lien S (2009) BAC-based upgrading and physical integration of a genetic SNP map in Atlantic salmon. Anim Genet 41:48-54. doi:10.1111/j.1365-2052.2009.01963.x

MacDonald A, Harris M (2004) Hepatitis C virus NS5A: tales of a promiscuous protein. J Gen Virol 85:2485-2502

McBeath AJA, Snow M, Secombes CJ, Ellis AE, Collet B (2007) Expression kinetics of interferon and interferon-induced genes in Atlantic salmon (Salmo salar) following infection with infectious pancreatic necrosis virus and infectious salmon anaemia virus. Fish Shellfish Immunol 22:230-241

Moen T, Fjalestad KT, Munck H, Gomez-Raya L (2004a) A multi-stage testing strategy for detection of quantitative trait loci affecting disease resistance in Atlantic salmon. Genetics 167:851-858

Moen T, Hoyheim B, Munck H, Gomez-Raya L (2004b) A linkage map of Atlantic salmon (Salmo salar) reveals an uncommonly large difference in recombination rate between the sexes. Anim Genet 35:81-92

Moen T, Sonesson AK, Hayes B, Lien S, Munck H, Meuwissen THE (2007) Mapping of a quantitative trait locus for resistance against infectious salmon anemia in Atlantic salmon (Salmo salar): comparing survival analysis with analysis on affected/resistant data. BMC Genet 8:53

Moen T, Hayes B, Baranski M, Berg PR, Kjoglum S, Koop BF, Davidson WS, Omholt SW, Lien S (2008) A linkage map of the Atlantic salmon (Salmo salar) based on EST-derived SNP markers. BMC Genomics 9:223

Ng SH, Artieri CG, Bosdet IE, Chiu R, Danzmann RG, Davidson WS, Ferguson MM, Fjell CD, Hoyheim B, Jones SJ, de Jong PJ, Koop BF, Krzywinski MI, Lubieniecki K, Marra MA, Mitchell LA, Mathewson C, Osoegawa K, Parisotto SE, Phillips RB, Rise ML, von Schalburg KR, Schein JE, Shin H, Siddigui A, Thorsen J, Wye N, Yang G, Zhu B (2005) A physical map of the genome of Atlantic salmon, Salmo salar. Genomics $86: 396-404$

Nomura N, Zhao M-J, Nagase T, Maekawa T, Ishizaki R, Tabata S, Ishii S (1991) HIV-EP2, a new member of the gene family encoding the human immunodeficiency virus type 1 enhancer binding protein. J Biol Chem 266:8590-8594

Phillips RB, Keatley KA, Morasch MR, Ventura AB, Lubieniecki KP, Koop BF, Danzmann RG, Davidson WS (2009) Assignment of Atlantic salmon (Salmo salar) linkage groups to specific chromosomes: conservation of large syntenic blocks corresponding to whole chromosome arms in rainbow trout (Oncorhynchus mykiss). BMC Genet 10:46

Quinn NL, Levenkova N, Chow W, Bouffard P, Boroevich KA, Knight JR, Jarvie TP, Lubieniecki KP, Desany BA, Koop BF, Harkins TT, Davidson WS (2008) Assessing the feasibility of GS FLX pyrosequencing for sequencing the Atlantic salmon genome. BMC Genomics 9:404
Rimstad E, Mjaaland S (2002) Infectious salmon anemia virus: an orthomyxovirus causing an emerging infection in Atlantic salmon. APMIS 110:273-282

Rise ML, von Schalburg KR, Brown GD, Devlin RH, Mawer MA, Kuipers N, Busby M, Beetz-Sargent M, Alberto R, Gibbs AR, Hunt P, Shukin R, Zeznik JA, Nelson C, Jones SRM, Smailus DE, Jones SJM, Schein JE, Marra MA, Butterfield YSN, Stott JM, Ng SH, Davidson WS, Koop BF (2004) Development and application of a salmonid EST database and cDNA microarray: data mining and interspecific hybridization characteristics. Genome Res 14:478-490

Robertsen B (2008) Expression of interferon and interferon-induced genes in salmonids in response to virus infection, interferon-inducing compounds and vaccination. Fish Shellfish Immunol 25:351-357

Rychlik W, Rhoads RE (1989) A computer program for choosing optimal oligonucleotides for filter hybridization, sequencing and in vitro amplification of DNA. Nucleic Acids Res 17:8543-8551

Sarropoulou E, Nousdili D, Magoulas A, Kotoulas G (2008) Linking the genomes of nonmodel teleosts through comparative genomics. Mar Biotechnol 10:227-233

Schiøtz BL, Jørgensen SM, Rexroad C, Gjøen T, Krasnov A (2008) Transcriptomic analysis of responses to infectious salmon anemia virus infection in macrophage-like cells. Virus Res 136:65-74

Srivastava B, Blazejewska P, Heßmann M, Bruder D, Geffers R, Mauel S, Gruber AD, Schughart K (2009) Host genetic background strongly influences the response to influenza A virus infections. PLoS ONE 4(3):e4857

Tailor CSD, Lavillette D, Marin M, Kabat D (2003) Cell surface receptors for gammaretroviruses. Curr Top Microbiol Immunol 281:29-106

Takeda K, Kaisho S, Akira S (2003) Toll-like receptors. Annu Rev Immunol 21:335-376

Thorsen J, Zhu B, Frengen E, Osoegawa K, de Jong PJ, Koop BF, Davidson WS, Hoyheim B (2005) A highly redundant BAC library of Atlantic salmon (Salmo salar): an important tool for salmon projects. BMC Genomics 6:50

Thorud K, Djupvik HO (1988) Infectious anemia in Atlantic salmon (Salmo salar L.). Bull Eur Assoc Fish Pathol 8:109-111

Tsoi S, Park KC, Kay HH, O’Brien TJ, Podor E, Sun G, Duglas SE, Brown LL, Johnson SC (2007) Identification of a transcript encoding a soluble form of toll-like receptor 5 (TLR5) in Atlantic salmon during Aeromonas salmonicida infection. Vet Immunol Immunopathol 109:183-187

Van't Veer LJ, Lutz PM, Isselbacher KJ, Bernards R (1992) Structure and expression of major histocompatibility complex-binding protein 2, a $275-\mathrm{kDa}$ zinc finger protein that binds to an enhancer of major histocompatibility complex clas I genes. Proc Natl Acad Sci USA 89:8971-8975

von Schalburg KR, Rise ML, Cooper GA, Brown GD, Gibbs RA, Nelson CC, Davidson WS, Koop BF (2008) Fish and chips: various methodologies demonstrate the utility of a 16,000-gene salmonid microarray. BMC Genomics 6:126-144

Workenhe ST, Kibenge MJ, Wright GM, Wadowska DW, Groman DB, Kibenge FS (2008) Infectious salmon anemia virus replication and induction of alpha feron in Atlantic salmon erythrocytes. Virol J 5:36

Workenhe ST, Hori TS, Rise ML, Kibenge MJ, Kibenge FS (2009) Infectious salmon anemia virus (ISAV) isolates induce distinct gene expression responses in the Atlantic salmon macrophage/ dendritic-like cell line TO assessed using genomic techniques. Mol Immunol 46:2955-2974

Yang Q, Cheng J, Liu Y, Hong Y, Wang JJ, Zhang SJ (2004) Cloning and identification of NS5ATP2 gene and its spliced variant transactivated by hepatitis $\mathrm{C}$ virus non-structural protein $5 \mathrm{~A}$. World J Gastroenterol 10:1735-1739 